\title{
PLEA BARGAINING AT THE INTERNATIONAL CRIMINAL TRIBUNAL FOR THE FORMER YUGOSLAVIA
}

\author{
RALPH HENHAM AND MARK DRUMBL ${ }^{*}$
}

The International Criminal Tribunal for the former Yugoslavia (ICTY) increasingly has turned to plea bargains to resolve the cases before it. A number of factors motor this trend. One is administrative: the ICTY has been subject to considerable pressure from the United Nations Security Council and donor states to accelerate its work. ${ }^{1}$ Another is the desire to obtain acknowledgements of responsibility from perpetrators. Moreover, there is concern that, as time passes, the memories of witnesses dim. The rigours of direct and cross examination may retraumatise those who have survived mass atrocity. ICTY judges also have expressed their understanding that guilty pleas promote reconciliation in areas afflicted by violence $^{2}$ and the rehabilitation of offenders. ${ }^{3}$ Plea bargaining also may serve important political purposes for the ICTY with regard to its relationships with peacekeepers and administrators throughout the territory of the former Yugoslavia. ${ }^{4}$

Plea bargains initially were disfavoured by the ICTY. ${ }^{5}$ Amendments to the ICTY's positive law documents, however, have since encouraged plea bargains. ${ }^{6}$ Assuredly, plea bargains also are permitted by the positive law of other international criminal justice institutions and have surfaced in the jurisprudence and case managements strategies of those institutions. ${ }^{7}$ The

\section{1}

Marlise Simons, Plea Deals Being Used to Clear Balkans War Tribunal's Docket, N.Y. TIMES (Nov. 18 2003).

Prosecutor v. Deronjić, Case No. IT-02-61-S (ICTY Trial Chamber, March 30, 2004), para. 134.

Deronjić, separate opinion of Judge Mumba, para. 2.

For example, in the Todorović case, the Prosecution withdrew a large number of counts and settled on a plea process and thereby obviated of Todorović's defences, namely that he had been kidnapped and held illegally by NATO SFOR forces.

$5 \quad$ Michael Scharf, BaLKan Justice 67 (1997); Nancy Amoury Combs, International Decisions: Prosecutor v. Plavšić, 97 AM. J. INT’L L. 929, 934 (2003).

$6 \quad$ See ICTY Rules of Procedure and Evidence, Rules 62bis, 62ter (permitting both guilty pleas and plea agreements, although plea agreements have been preferred in practice).

ICTR Rules of Procedure and Evidence, Rules 62, 62(B); Sierra Leone Special Court Rules of Procedure and Evidence, Rule 62. The East Timor panels also encourage plea bargaining, citing among other benefits the fact that it aides in the administration of justice. Prosecutor v. João Fernandez, Case No. 01/00.C.G.2000 (January 25, 2000), Dili District Court, Special Panel for Serious Crimes, para. 20, aff'd Court of Appeal, Criminal Appeal N. 2001/12 (July 29, 2001); Prosecutor v. João Franca da Silva, Case 
ICTY's turn to plea bargains, however, is sharp. Moreover, it touches much more than pragmatic case management concerns. For example, it implicates sentencing: to what extent can plea bargains mitigate sentence? Do they operate in addition to other closely related factors, such as cooperation with the prosecution, remorse, acceptance of responsibility, or voluntary surrender? Plea bargaining also implicates the Prosecutor's recourse to joint criminal liability theories: to what extent can negotiated testimony inculpate other defendants? The turn to plea bargains affects the ICTY's relationships with national courts. On this latter note, it remains unclear whether charges dropped by the ICTY Prosecutor as part of a plea agreement can be pursued by such courts exercising jurisdiction on the basis of nationality, territoriality, or universality. Plea bargains also present a complex interface with the trial ideologies of the ICTY, in particular retributivism.

At this stage, we think it helpful to clarify what exactly is meant by 'plea bargain' as operationalised in the work of the ICTY. As we understand it, the term plea bargain actually contemplates two different concepts, as well as a number of variations between the two.

At one end of the spectrum is the admission of guilt, referred to by the ICTY as the "pure guilty plea. ${ }^{8}$ Here, ideally the defendant comes forward, pleads guilty to the charges in the indictment, pledges to cooperate, conveys remorse, and accepts responsibility - all without expressly contracting for anything in return. The Trial Chamber, then, may consider the plea as a mitigating factor in sentencing; before reaching this stage, however, the Trial Chamber must be satisfied that there is a sufficient factual basis for the crime and for the accused's participation in it and that the plea was voluntary, informed and unequivocal. ${ }^{9}$ Generally speaking, this is the procedure contemplated by Rules 62(VI) and 62bis of the ICTY Rules. The pure guilty plea is not a concept historically alien to international criminal tribunals. ${ }^{10}$

No. 04a/2001 (December 5, 2001), Dili District Court, Special Panel for Serious Crimes, para 145; Prosecutor v. Agustinho Atolan, Case No. 3/2003 (June 9, 2003), Dili District Court, Special Panel for Serious Crimes, p. 7.

$8 \quad$ Deronjić, para. 135.

Prosecutor v. Todorović, Case No. IT-95-9/1 (ICTY Trial Chamber, July 31, 2001), para. 23. In making these assessments, the Trial Chamber may rely on independent indicia or on the lack of material disagreement between the accused and the Prosecution regarding the facts of the case.

10 Geert-Jan Alexander Knoops, AN INTRODUCTION TO THE LAW OF INTERNATIONAL CRIMINAL TRIBUNALS: A COMPARATIVE STUDY 113 (2003) (citing art. 24(b) of the IMT Charter and art. 15(b) of the IMTFE Charter). The guilty plea of Jean Kambanda (the Prime Minister of Rwanda at the time of the genocide) before the ICTR trends toward the traditional understanding of the pure guilty plea, insofar as 
At the other end is the 'charge bargain' or, in the words of ICTY Rule 62 ter, the 'plea agreement.' Here, the defendant agrees to plead guilty to some of the charges in the indictment (or perhaps just one charge) in exchange for a variety of deliberately negotiated discounts. These discounts range from the Prosecutor's agreeing to drop certain other charges, to provide guarantees against self-incrimination, to commit not to use any evidence provided in legal proceedings against the defendant in the future, and to reduce sentence. Not all plea agreements include all of these discounts: there is heterogeneity in the content of various agreements. In exchange, the Prosecution itself may bargain for the testimony of that defendant in proceedings involving other defendants, including high-profile defendants such as Slobodan Milosevic, ${ }^{11}$ although there is a moral hazard problem insofar as it may be difficult to judge ex ante the value, legitimacy, and credibility of the testimony. In some plea agreements, the Prosecution commits to recommend a particular sentence or not to recommend a sentence beyond a certain level of severity. ${ }^{12}$ In other cases, the Prosecution agrees to a sentencing range and commits not to appeal any sentence imposed within that range (the defendant also may agree not to appeal any sentence within that range). ${ }^{13}$ In both of these situations (which, interestingly, have arisen under pleas entered under Rules 62bis and 62ter, which we discuss later), prosecutorial bargaining appears de facto to impinge on the power of the Trial Chamber to sentence, even though formally under Rule 62ter(B) the Trial Chamber is not bound by any agreement between the parties. Once the Prosecutor begins to make these bargains, the incentive to bargain may be undercut if the Trial Chamber routinely refuses to honour the recommendations. The Trial Chamber may

Kambanda pleaded guilty to all charges in the indictment (including genocide), acknowledged responsibility, and did not receive a reduced sentence (he was given life imprisonment). His subsequent attempts to appeal the sentence were unsuccessful.

${ }_{11}$ See e.g. Prosecutor v. Babić, Case No. IT-03-72-S (ICTY Trial Chamber, June 29, 2004) paras. $65,69,73$.

12 See e.g. Prosecutor v. Jokić, Case No. IT-01-42/1-S (ICTY Trial Chamber, March 18, 2004) para. 69 (plea agreement contains a commitment by the Prosecution to recommend a sentence of no more than 10 years' imprisonment; the Trial Chamber awarded a sentence of 7 years); Babić, para. 9 (plea agreement contains a stipulation that the Prosecution would recommend that the Trial Chamber impose a sentence of no more than 11 years).

13 Prosecutor v. Češić, Case No. IT-95-10/1-S (ICTY Trial Chamber, March 11, 2004) para. 105; Prosecutor v. Obrenović, Case No. IT-02-60/2-S (ICTY Trial Chamber, December 10, 2003) para. 16, 147 (plea agreement stipulates that the Prosecution will recommend that the Trial Chamber impose a sentence within the range of 15 to 20 years); Prosecutor v. Sikirica, Dosen, and Kolundžija, Case No. IT-95-8 (ICTY Trial Chamber, November 13, 2001) para. 29 (Prosecution and Defence agree that the Prosecution would recommend a range of five to seven years and that neither party would appeal any sentence imposed by the Trial Chamber within that range). 
be sensitive to these incentives, with the result that Prosecutorial authority and discretion will increase. In practice, however, there have been a number of important cases where the Trial Chamber has refused to honour the sentencing recommendation in the plea agreement. ${ }^{14}$

In short, the ICTY has gone well beyond the quintessential admission of guilt to enter into a framework of negotiated bargaining and, in this process, has legitimated a variety of exchanges. The plea agreement, in particular the charge bargain, has elicited controversy.

Our concern is that plea agreements remain an undertheorised element of the work of the ICTY despite the reality that they are increasingly becoming normalised - seemingly to further pragmatic ends - as official ICTY institutional policy. What we hope to achieve in this article is to suggest theoretical frameworks in which plea agreements can be analysed and assessed, with a particular focus on the effects of plea bargaining on the expressed ideological, penological, and reconciliatory rationales of the ICTY. We come to these suggestions through a review of the positive law structure of plea bargaining in ICTY foundational documents, preceded by a discussion of some of the ICTY's recent sentencing decisions involving plea-bargained convictions. We also note the emergence of dissensus among ICTY judges regarding plea bargains, for example in the Deronjic and Momir Nikolić cases, and hope to structure some sort of conceptual framework in which this dissensus can be articulated or, at least, channeled. We also hope to flag certain areas of concern for the viability of plea bargains. In particular, we worry about the extent to which the institutionalisation of plea agreements blocks the articulation of competing trial ideologies, in particular restorative approaches, while exaggerating the effects such negotiated agreements have on reconciliation and truth-telling. In both of these cases, the pragmatic justifications for plea bargains mask broader longer-term legitimacy concerns. These concerns also are germane to the International Criminal Court (ICC) when it begins its work, and whose positive law of plea bargaining we also consider.

\section{A. Effects of Plea Bargains: Recent Cases}

14 For example, in Babic the Trial Chamber imposed a sentence of 13 years despite plea agreement recommendation of no more than 11. See also discussion infra note 
As of the fall of 2004, seventeen individuals indicted by the ICTY Prosecutor have entered guilty pleas. 33 cases have proceeded through full trial, leading to four acquittals and 29 convictions (some of which still remain subject to appeal). The plea bargain therefore plays an important role in the praxis of the ICTY, securing over one-third of all convictions.

What is more, plea bargains play some role in mitigating sentence, ${ }^{15}$ although this may not be as decisive in the actual quantum of sentencing as critics of the plea bargain process may fear. Excluding the ICTY's single life sentence, ${ }^{16}$ the mean and median sentences for those convicted following trial are 16.4 and 17 years respectively. ${ }^{17}$ Many of these sentences are under appeal This is relevant insofar as the ICTY Appeals Chamber has been somewhat activist in terms of revisiting Trial Chambers sentences. For example, the two heaviest term sentences, 46 years to General Krstić and 45 years to General Blaškić (both issued following conviction by trial), were subsequently reduced by the Appeals Chamber to 35 and 9 years respectively. The mean and median sentences for those who have entered guilty pleas are 13.8 and 11 years respectively. Some of these plea bargained sentences also remain subject to appeal.

There are, however, a number of important caveats to the ICTY data. First, included within the mean is the 40 year sentence to Goran Jelisić, who pleaded guilty to crimes against humanity and then went to trial on a single genocide charge, of which he was acquitted. This case is somewhat of an outlier, ${ }^{18}$ insofar as it constitutes the ICTY's heaviest overall final term

\footnotetext{
15 Combs, supra note _, at 935. Plea bargains also mitigate sentence for defendants before other international criminal justice institutions. As for the ICTR, only three accused have pleaded guilty. This is a much more modest number than that found at the ICTY. That said, all of the ICTR's lowest sentences have involved convictions secured through guilty pleas. Plea agreements or charge bargains have not yet been used at the ICTR. In terms of quantification of sentence, those who plead guilty in East Timor receive a significant discount. In fact, the East Timor panels have shown a 'markedly lenient approach' to those who plead guilty, entitling these individuals to a material reduction of the sentence that would otherwise be imposed (cutting around half of the sentence). Atolan, p. 7. For this panel, remorse 'is [...] of minor importance[,] [...] what matters is the practical [...] cooperation with the prosecutor.' Atolan, pp. 7-8.

${ }_{16}$ Prosecutor v. Stakić, Case No. IT-97-24 (ICTY Trial Chamber, July 31, 2003). The sentence remains under appeal.

17 Data compiled from Fact Sheet on ICTY Proceedings, available at http://www.un.org/icty/cases/factsheets/procfact-e.htm (Nov. 4, 2004).

Jelisic is an early case (the second guilty plea entered before the ICTY), decided by the Trial Chamber orally on October 19, 1999 and in writing on December 14, 1999; the forty-year sentence was unanimously affirmed by the Appeals Chamber on July 5, 2001. Prosecutor v. Goran Jelisić, Case No. IT95-10-A (ICTY Trial Chamber, December 14, 1999; ICTY Appeals Chamber, July 5, 2001). In Jelisić, as was the case in Erdemovic (the first guilty plea entered at the ICTY), the Prosecution did not bargain to obtain the plea. Plea bargains began in earnest following the Todorovic plea in December 2000.
} 
sentence, and thereby may upwardly distort the mean plea- bargained sentence. The second longest plea-bargained sentence is 27 years to Momir Nikolić (which is currently under appeal). Second, and more important, is the reality that the extent to which the charge bargain affects overall sentencing data is extremely difficult to measure. Many of the individuals who pleaded guilty did so contingent on the dropping of other charges and often entered guilty pleas only to a handful of charges. In many cases, at least three counts are dropped. These often include serious crimes against humanity charges (e.g. Banović, Mrdja, Momir Nikolić, Plavšić, Obrenović, Todorović, Milan Simić) and also war crimes charges (e.g. Babić, Jokić). In particular, in three cases genocide charges were dropped as part of the plea (Momir Nikolić, Obrenović, Plavšić). The ICTY's one conviction on genocide (through trial and appeal following a not-guilty plea), which occurred only on a secondary liability theory of aiding and abetting genocide, resulted in a thirty-five year sentence. This is a much heavier sentence than that issued to any person convicted after a guilty plea other than Jelisić. To be sure, it may be that acquittals (or dismissals) would result were the bargained-away genocide charges actually to have gone to trial, as has been the case in the past. That said, the phenomenon of charge bargaining makes it difficult to compare the sentencing data between offenders who plead guilty and offenders convicted pursuant to a trial. We would hazard that a modeling calibration that factored in the effects of charge bargaining on the aggregate sentencing data would yield an expansion in the preexisting differences between the severity of punishment on the group of offenders who were convicted following a plea bargain and those convicted following a full trial.

Furthermore, the declaratory value of plea bargains as mitigating factors in sentencing is robust. ICTY judges state clearly and frequently that guilty pleas are to be a significant factor in mitigating sentence. ${ }^{19}$ In Todorovic', it was held that a guilty plea 'should, in principle, give rise to a reduction in the sentence that the accused would otherwise have received;' 20 in Sikirica, the Trial Chamber cited the guilty plea as the 'primary factor' to be considered in mitigation of the defendant's sentence; ${ }^{21}$ and in Plavšić, it

\footnotetext{
19 Prosecutor v. Plavšić, Case No. IT-00-39\&40/1-S (ICTY Trial Chamber, Feb. 27, 2003), para. 110; Obrenović, para. 116 (guilty plea as a 'significant factor in mitigation of the sentence'). As for the justification of guilty pleas at the ICTR, see Prosecutor v. Ruggiu, ICTR-97-32-T (ICTR Trial Chamber, June 1, 2000), para. 53 (guilty pleas inter alia expedite proceedings and save resources).

$20 \quad$ Todorović, para. 80.

21 Prosecutor v. Sikirica, Case No. IT-95-8-S (ICTY Trial Chamber, November 13, 2001) para. 148.
} 
was held proper to accord 'significant weight' to the guilty plea. ${ }^{22}$ In Mrdja, the Trial Chamber noted that the ICTY's case-law has

commonly accepted a guilty plea as a circumstance in mitigation of sentence for the following reasons: a guilty plea may demonstrate honesty, helps to establish the truth, may contribute to peace-building and reconciliation, and saves the Tribunal the time and resources of a lengthy trial. Moreover, victims and witnesses are relieved from the possible stress of testifying at trial. ${ }^{23}$

In Mrdja, the Trial Chamber accepted that the plea helped establish the truth regarding the crimes committed on one day in one place and, 'thus, in the long term, it may encourage reconciliation among the peoples of Bosnia and Herzegovina. ${ }^{24}$ This rationale is found in other recent plea bargain sentencing decisions, for example Jokić. ${ }^{25}$ The ICTY also has noted that a guilty plea process encourages accused persons to come forward. ${ }^{26}$ Judicial economy concerns figure repeatedly in the ICTY's endorsements of plea bargaining. ${ }^{27}$

\section{(a) Plea Bargaining, Retribution, Predictability, and Discretion}

The pragmatic goals of plea bargaining are at odds with the goals of punishment affirmed by the ICTY. The ICTY cites retribution, deterrence, and rehabilitation among the goals of the punishment it levies. A review of the jurisprudence of the ICTY reveals that these goals are not co-equal and that primary importance is accorded to retribution. ${ }^{28}$ Paradoxically, however, plea bargains compete with the notion that perpetrators deserve to be punished. For example, by punishing persons differently based on administrative contingencies, the ICTY moves away from punishing people differently based on the gravity of the crime or the level of their desert. Within the plea bargain framework, the bald reality is that perpetrators having information on others tend to be given a better bargain than those

\footnotetext{
$22 \quad$ Plavšić, para. 81.

23 Prosecutor v. Mrdja, Case No. IT-02-59-S (ICTY Trial Chamber, March 31, 2004) para. 78).

$24 \quad$ Mrdja, para. 79.

25 Jokić, paras. 76-77.

26 Prosecutor v. Banović, Case No. IT-02-65/1-S (ICTY Trial Chamber, October 28, 2003), paras. 66,68 .

27 See e.g. Sikirica para. 149 (noting that a guilty plea saves the international tribunal the time and effort of a lengthy investigation and trial).

28 Mark A. Drumbl, Collective Violence and Individual Punishment: The Criminality of Mass Atrocity, 99 NORTHWESTERN U. LAW REVIEW (2005)
} 
with nothing to offer. ${ }^{29}$ A perpetrator involved in a joint criminal enterprise with high-profile suspects may benefit greatly from the discount (especially if the cases against those high-profile suspects are weak) regardless of the egregiousness of the crimes committed. These strategic concerns also weaken the deterrent function of punishment, insofar as sentencing becomes contingent on factors that have nothing to do with the perpetrator's ability to encourage recidivism among others (general deterrence) or the perpetrator's own propensity to re-offend (specific deterrence). Moreover, the ICTY has held that guilty pleas are important insofar as they may protect victims from having to testify. ${ }^{30}$ This, of course, obfuscates the fact that, for some victims, testifying may have significant cathartic value, allowing them to engage with a broad spectrum of emotions and needs ranging from vengeance through to a fervent desire to make a personal contribution towards establishing what they regard as the 'truth'. 31

In the end, a disjuncture emerges insofar as the administrative and bureaucratic factors that animate plea bargaining may run at cross-purposes to the rationales that have been adopted by the ICTY to justify the severity or leniency of punishment. Although there is nothing improper per se in including new factors in the schema of punishment indicators, it is problematic to do so without amending the punishment rationales themselves. To be sure, it could be argued that securing testimony and information through negotiated bargains may result in more convictions of individuals who would otherwise be acquitted or simply not indicted. This, in turn, augments overall retribution. This argument, however, has not been articulated as a punishment rationale by the international criminal tribunals, for whom sentencing remains an individualised matter.

Retributive concerns arise not only when offenders who plea bargain are compared to offenders who go to trial, but also when comparisons are made within the group of offenders who plea bargain. In fact, a retributivist would see little coherence in the sentences issued by the ICTY following plea bargains. Let us consider the following examples. On the one hand, Biljana Plavšić, a top Bosnian Serb leader involved in the planning of some

\footnotetext{
29 Assuredly, these disparities also are found in municipal criminal law, in particular regarding the sentencing of drug offenders and criminal syndicates, where they have sparked critical commentary and concern.

30 Todorović, paras. 89-92.

31 Arguably, the rights of victims in this respect should be legally recognised; see Helen Fenwick Procedural Rights of Victims of Crime: Public or Private Ordering of the Criminal Justice Process 60 MODERN LAW REVIEW (1997) 317.
} 
of the gravest atrocities in Bosnia (forced expulsion of hundreds of thousands of non-Serbs, destruction of 850 non-Serb villages, killings of many thousands of individuals, widespread sexual assault, and inhumane destruction), ${ }^{32}$ was sentenced to 11 years. This prompted '[v]ictims [to] react[] with predictable outrage,' in particular when they learned that 'Plavšić was sent to serve her term in a posh Swedish prison that reportedly provides prisoners with use of a sauna, solarium, massage room, and horseriding paddock, among other amenities. ${ }^{33}$ On the other hand, rebel Croatian Serb leader Milan Babić, much further down on the leadership hierarchy and who agreed to testify against Slobodan Milošević - received a sentence of 13 years for his role in a campaign to expel non-Serbs. The 13 years' imprisonment issued to Babic surpassed the 11 years recommended by the Prosecution, whereas the 11 years imposed on Plavšić was far below the Prosecutor's recommendation of between 15 and 25 years.

Plavšić's sentence is only four years longer than that issued to Miodrag Jokić, who pleaded guilty to war crimes charges related to the shelling of Dubrovnik involving the destruction of cultural property and the deaths of two civilians and the wounding of three others. Moreover, Plavšić's sentence is 16 years shorter than that of Momir Nikolić, a security and intelligence officer of much more modest status who was charged in connection with Srebrenica but was not involved in the wider Serb assaults throughout Bosnia and Herzegovina. Whereas Darko Mrdja was sentenced to 17 years after pleading guilty to direct involvement in the shooting of 200 persons (only 12 of whom survived), Ranko Češić, a Bosnian Serb police reservist, was sentenced to 18 years for pleading guilty to beating to death ten prisoners and sexually assaulting (in especially gruesome fashion) two others. Češić's punishment contrasts with the 10 year sentence imposed on Miroslav Deronjić, an influential civilian leader who substantially participated in a joint criminal enterprise that ordered the razing of the village of Glogova, in which 64 Bosnian Muslims civilians were killed and many more forcibly displaced.

To be sure, it is difficult to compare atrocious crimes through the use of indicators of gravity focused on numbers of victims. That said, the scope of the crime is an important indicator of gravity. So, too, is the position of the accused in the leadership hierarchy, insofar as senior status suggests the

Plavšić, paras. 16, 42.

See Combs, supra note _, at 936. 
power to have blocked or ignored the administrative orders that serve as the starting point of mass violence. A review of plea bargained cases, however, suggests that these retributive rationales do not inform sentencing in a predictable manner and that intervening strategic rationales regarding plea negotiations may be a cause of this lack of predictability. The fact that bureaucratic constraints and managerial dictates now affect the fate of many 'enemies of all humankind' weakens the ICTY's retributive authority. What is more, if a purpose of retribution might be for individual victims to see punishment inflicted on the criminal, victims should play a role in determining whether or not a plea should be accepted and on which terms. ${ }^{34}$ In the end, although this variability in terms of plea bargained sentences could be lauded as the individualisation of sentencing, the lack of an ordering heuristic suggests a more troubling absence of predictability that erodes the retributive value of punishment, along with secondary rationales such as deterrence, expressivism, and rehabilitation.

That said, the purpose of this exercise is not to propound the merits of retributive approaches. In fact, we share deep concerns over such approaches, both within municipal criminal law as well as international criminal law. The purpose, instead, is to flag our concerns with judicialised governance systems that claim a certain punishment ideology but then utilise indicators to enforce that ideology that are inconsistent, disconnected, and unpredictable.

\section{(b) Plea Bargains and the Systematisation of Mitigation in Sentencing}

The jurisprudence evidences a paucity of clear principles as to how pleading guilty intersects with other mitigating factors, leading to the phenomenon of what we identify as a praxis of cumulative mitigation. More specifically, once an offender plea bargains, does that automatically entitle the offender to a broader number of additional mitigating discounts because that offender then also can claim acceptance of responsibility, substantial cooperation with prosecution, remorse, and voluntary surrender?

The jurisprudence is somewhat fragmented. In the Češić case, the prosecution 'did aver that mitigation for remorse is separate to and distinct

34 The ICC Rules permit some victim involvement in the evaluation of an admission of guilt. See ICC Rules of Procedure and Evidence, available at http://www.icc-cpi.int/php/show.php?id=rules, Rule 139. 
from mitigation arising from a guilty plea. ${ }^{35}$ On the other hand, in Plavšić, the judges held that the remorse was 'part of the mitigating circumstances connected with a guilty plea' insofar as it was arguable that by the plea the defendant already had demonstrated remorse. ${ }^{36}$ In Jelisić, the plea had limited effect in mitigation because the Trial Chamber felt the expression of remorse was not sincere ${ }^{37}$ and that the cooperation was not compelling. ${ }^{38}$ The Jelisić approach is more similar to that in Češić in the sense that these closely related factors are viewed separately and, in Jelisić's unusual case, in tension with each other. Differentiating the guilty plea from remorse and cooperation as independent factors in mitigation (despite their close connection) serves the benefit of discounting overall mitigation in cases where the co-operation over time may prove to be duplicitous. For example, the Trial Chamber found Momir Nikolić's subsequent testimony to be evasive and previous statements to have been false. ${ }^{39}$ It thereby separately mitigated his sentence because of the plea but not because of cooperation, instead of discounting the overall value of the plea bargain as an element in mitigation. In the end, though, it seems odd to accept a guilty plea when there is no remorse or cooperation: the retributive, expressive, and narrative effects of such a plea seem thin. The managerial aspects would be the only benefit that remains, thereby giving rise to the concerns regarding the influence of pragmatics on ICTY penology that we explore in Part C.(a) below.

That said, there does appear to be a practice of cumulative mitigation. This is found not only at the ICTY, but also in the work of other

\footnotetext{
35 Češić, para. 65. Remorse was dealt with as a separate mitigating factor in Todorović, unconnected with rationales which might justify the guilty plea discount. Todorović, paras 89-92, 114. The Trial Chamber accepted the defendant's remorse as genuine, and appeared particularly impressed by his expressed desire to 'channel his remorse into positive action to reconciliation in Bosnia and Herzegovina', although this was expressed more by way of sentiment than intended action on the part of the defendant. Id. paras. 90 and 91 . More generally, it is worth noting that the doctrinal basis for treating remorse as a mitigating factor has been challenged; see M Bagaric and K Amarasekara Feeling Sorry? - Tell Someone who Cares: The Irrelevance of Remorse in Sentencing, 40 HOWARD JOURNAL OF CRIMINAL JUSTICE (2001) 364.

$36 \quad$ Plavšić, para. 73.

37 Jelisić Trial Judgement, para. 127 (affirmed on appeal).

38 Jelisić Appeal judgement, para. 125. See also Jelisić Appeal Judgement, para. 121 (according considerable discretion to the Trial Chamber in terms of weighing the value of a guilty plea by holding that ' $[t]$ he Statute and Rules leave it open to the Trial Chamber to consider the mitigating effect of a guilty plea on the basis that the mitigating weight to be attached to the plea lies in the discretion of the Trial Chamber.')

39 Prosecutor v. Momir Nikolić, Case No. IT-02-60/1-S (ICTY Trial Chamber, December 2, 2003) para. 156).
} 
international criminal justice institutions. ${ }^{40}$ By way of example, mitigating factors in Deronjić's sentence included the guilty plea, ${ }^{41}$ the acceptance of responsibility, ${ }^{42}$ cooperation with the prosecution ${ }^{43}$ and remorse. ${ }^{44}$ In the Mrdja case, cooperation with prosecution, ${ }^{45}$ guilty plea, ${ }^{46}$ and remorse ${ }^{47}$ were considered synergistically; in Jokić, mitigating factors included voluntary surrender, ${ }^{48}$ guilty plea and acceptance of responsibility, ${ }^{49}$ remorse, ${ }^{50}$ and cooperation with the prosecution; ${ }^{51}$ and in Češic the mitigating factors were the guilty plea, ${ }^{52}$ cooperation with the prosecution, ${ }^{53}$ and remorse. ${ }^{54}$ What is more, in Mrdja, '[t] $]$ he Prosecution did not challenge the claim that an accused's remorse is a potential factor in mitigation and that it is independent of other circumstances, such as a guilty plea. ${ }^{55} \mathrm{Mrdja}$ also demonstrates that the Trial Chamber can consider cooperation with the Prosecution as an independent mitigating factor, even though cooperation was an explicit term of the guilty plea negotiated between the defendant and Prosecution. Accordingly, the Trial Chamber credited Mrdja for cooperation when that cooperation already was a central commitment of another factor cited in mitigation, namely the guilty plea agreement. ${ }^{56}$ A similar phenomenon emerges in the Jokić sentencing decision, in which the defendant is lauded for his full and substantial cooperation with the Prosecution even though that cooperation was an explicit term of the plea agreement in which the Prosecution already had committed not to ask for more than a ten year sentence (along with a number of other concessions). ${ }^{57}$

\footnotetext{
40

Deronjić, para. 277.

Id.

Id. para. 278.

Id. para. 263-64.

Mrdja, paras. 74, 110.

Id. para. 77 (even if the plea is delayed)

Id. para. 110 .

Jokić, para. 73 .

Id. para. 78 (explicitly considered these together).

Id. para. 92 .

Id. para. 96 .

Češić, para. 60.

Id. para. 62 .

Id. para. 66 .

Mrdja, para. 84

Id. paras. 71-74, 100.

Jokić, para. 95.
} In Atolan, the East Timor Special Panel held that the plea was 'the most important and only relevant of the mitigating elements,' but then went on to discuss remorse (of minor importance) and cooperation with the prosecution (found to be something that matters). Atolan, pp 7-8. Therefore, although the East Timorese approach in this decision serves to assess the plea as an independent and free standing factor to which the expression of remorse as contained within the plea is inconsequential, it was not prepared to view cooperation with the prosecution, also part of the plea, in the same way. 
As we explore in Part B below, the concerns that arise in the jurisprudence regarding the intersection of the guilty plea with other mitigating factors in sentencing are at least in part traceable to the indeterminate language of the ICTY's positive law instruments.

(c) Plea Bargaining and the Interface between International and National Courts

What is the effect of charge bargaining at the international tribunals on the coincident or subsequent pursuit of charges by national or local courts? In other words, if a genocide charge is dropped by the ICTY as part of a negotiated plea agreement, does this preclude a national court properly exercising jurisdiction (whether based on territoriality, nationality, or universality) from pursuing that same genocide charge? In the event rules of understanding are not developed between international and national courts in an era where administrative pressures are prompting the international tribunals increasingly to consider referring cases to the national level, the incentive structure behind plea bargains may become threatened, for better or for worse. This also presents the problematic of disjointed proceedings at various levels against the same defendant for similar or related acts. Although, on the one hand, there is some merit in enforcing international criminal law through a myriad of diffuse institutions, on the other hand principles of judicial economy, stability, and precedent suggest the need to craft certain rules of understanding. Looking beyond administrative incentives, however, we note that formulating understandings will be essential if general principles of international criminal law, such as non bis in idem, are to be respected. Another important principle is the notion that there is a duty to prosecute certain extraordinary international crimes, such as genocide.

These concerns relate not only to the bringing of charges in national courts, but also the kind of evidence that can be adduced. The ICTY Prosecutor has agreed not to use evidence obtained from a defendant who plea bargains against that defendant before the ICTY. But can such guarantees bind national courts with jurisdiction, to which the ICTY increasingly is turning to discharge its workload?

\section{(d) An Emerging Dissensus?}


The ICTY has begun to voice some reserve regarding the general suitability of plea bargaining to international crimes and the legitimacy of certain individual plea agreements. This inchoate dissensus emerges tellingly in the Momir Nikolić decision, as well as both the majority and dissent in the Deronjić case. ${ }^{58}$ As discussed previously, Miroslav Deronjić was sentenced to 10 years for his role in the Glogova massacre. ${ }^{59}$ The Trial Chamber majority noted that the plea agreement in question was of the charge bargaining variety permitted under Rule 62ter. It noted that these sorts of bargains limited the factual record to that in the agreement itself and, what is more, suggested that an accused may confess 'only because of the principle 'do ut des' (give and take). ${ }^{60}$ The judges suggested that it was appropriate to analyse why an accused entered a guilty plea, specifically citing factors such as the withdrawal of charges or the issuance of sentence recommendation, ${ }^{61}$ but then ended up affirming the agreement in its entirety even though it was quite arguable that the Deronijic agreement on its face was one of do ut des. Although the Trial Chamber ruminated about the suitability of plea bargains for situations of mass atrocity - noting that in most municipal jurisdictions plea bargains did not apply to very serious crimes and did not affect the maximum statutory penalty - it ultimately accepted the plea bargain, including the ten year sentence recommended by the Prosecutor. ${ }^{62}$ It was motivated in this regard by what it saw as the greater need for truth-telling and reconciliation in the context of the work of the international tribunals than in the work of national legal systems. ${ }^{63} \mathrm{We}$

\footnotetext{
58 The decision of the Trial Chamber was authored by Judge Agius, to which Judge Mumba agreed in a separate opinion.

59 The sentence derived from the guilty plea, Deronjić's provision of evidence in five other ICTY trials, and his expression of remorse and responsibility. In addition, the ICTY Trial Chamber noted that Deronjić's confession and admission of all the factual details in the indictment (the second amended indictment, to be precise) 'has guided the international community closer to the truth on crimes committed in the area of Glogova, truth being one prerequisite to peace. He has helped, to a certain extent, to protect against any kind of revisionism.' Deronjić, para. 3. That said, this amended indictment was reduced to one charge (persecution as a crime against humanity) down from six counts in the first indictment. Deronjić, paras. 14,18 .

60 Id. para. 135; this is not the first time the principle of do ut des surfaces in the sentencing jurisprudence of the ICTY, insofar as it was referenced in Prosecutor v. Dragan Nikolić, Case No. IT-94-2S (ICTY Trial Chamber, December 18, 2003) para. 122.

61 Deronjić, para. 135.

62 Deronjić, paras. 135, 230, 280. See also dissenting judgement para. 14(b) (noting that in the majority of surveyed countries 'a guilty plea is given only little - if any - weight in relation to serious crimes. In Australia, Canada, China, England, and Germany, first degree murder attracts a mandatory sentence of life imprisonment that can not be altered by the acceptance of the guilty plea or confession of the accused.')

63 Deronjić, para 236.
} 
examine this justification, as well as the truth-telling and reconciliatory effects of plea bargains, in greater detail in Part $\mathrm{C}$ below.

Judge Schomburg dissented on sentence, concluding that Deronjić deserved a term of imprisonment of at least twenty years. He remarked that the ten year sentence was not proportional to the crimes in the agreement. ${ }^{64}$ In addition, Judge Schomburg expressed concern that the crimes pleaded were 'arbitrarily' presented from the context of a much larger criminal plan. ${ }^{65}$ Concern also was raised that Deronjić had admitted in his testimony that he had committed other crimes for which no indictments were issued.

The Momir Nikolić sentencing judgement, rendered on December 2, 2003, preceded Deronjić. In this sentencing judgement, the ICTY gave extensive critical thought to the plea agreement, in particular charge bargaining, which it urged should be treated with extreme caution given the Prosecutor's duty to prosecute serious violations of international humanitarian law. ${ }^{66}$ Nikolić's plea was for one count of persecutions as a crime against humanity and the remaining counts were dismissed, including a genocide charge. In its sentencing judgement, the ICTY was concerned with the extent of Nikolić's cooperation with the Prosecution, in particular the credibility and truthfulness of his testimony in other cases. ${ }^{67}$ Furthermore, the ICTY evinced a certain level of skepticism towards the 'negotiation' that effectively precedes many plea agreements. ${ }^{68}$ The Trial Chamber emphasised that it 'may' enter a finding of guilt based on the plea agreement as it has the discretion whether to accept the plea, noting also that

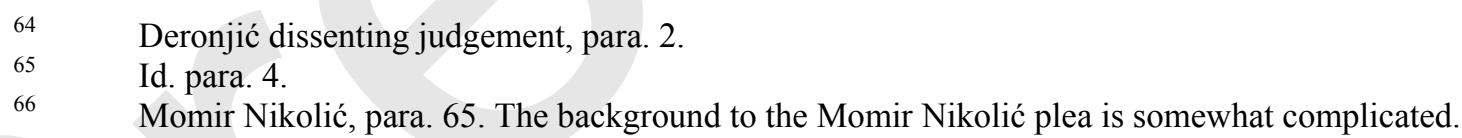
rejected a plea agreement conducted between the Prosecution and Nikolić because, inter alia, the Prosecutor had not agreed to dismiss the remaining charges until the time of sentencing. Momir Nikolić, para. 11. The essentially overturned agreement had stipulated the accused would confess to charges that included crimes against humanity and testify on behalf of the Prosecution in other cases regarding the Srebrenica massacre. In return, the prosecution agreed to dismiss genocide charges (and certain war crimes charges) and committed to request a reduced sentence due inter alia to the dismissal of the genocide charges. When called upon to validate this plea agreement, the Trial Chamber judges became hesitant. As Knoops observes, 'the agreement was unclear as to whether the prosecutor was empowered to prosecute the accused for the genocide charge in the event his confession would be found inadmissible, i.e. not equivocal and/or voluntary.' Knoops, supra note , at p. 115. Once this was remedied, the Trial Chambers accepted the plea agreement and reserved its judgement as to sentence. Under the terms of the plea agreement that was accepted, Nikolić agreed to cooperate with the Prosecution, provide truthful information, testify in the trial of a former co-accused and any other trial as requested, and not to appeal the sentence unless this is set outside the agreed upon range (15 to 20 years). Momir Nikolić, para. 17.

$67 \quad$ Momir Nikolić, para. 25.

68 Id. para. 48. 
it 'may also reject a particular guilty plea based on a plea agreement because it does not consider that the plea agreement is in the interests of justice. ${ }^{69}$ In a prescient observation germane to the theoretical independence of international criminal law, the Trial Chamber noted that there are important differences between national criminal justice systems that prosecute ordinary crimes and international systems that prosecute those who flout international humanitarian law. These differences suggest that transplanting plea bargaining frameworks from national courts to the ICTY (and other international criminal tribunals) should be viewed cautiously. In addition, the Trial Chamber made a number of conceptual critiques of plea bargains for extraordinary international crimes:

Convictions entered by a trial chamber must accurately reflect the actual conduct and crime committed and must not simply reflect the agreement of the parties as to what would be a suitable settlement of the matter. [...] The Trial Chamber notes that the savings of time and resources due to a guilty plea has often been considered as a valuable and justifiable reason for the promotion of guilty pleas. This Trial Chamber cannot fully endorse this argument. While it appreciates this saving of Tribunal resources, the Trial Chamber finds that in cases of this magnitude, where the Tribunal has been entrusted by the United Nations Security Council - and by extension, the international community as a whole - to bring justice to the former Yugoslavia through criminal proceedings that are fair, in accordance with international human rights standards, and accord due regard to the rights of the accused and the interests of victims, the savings of resources cannot be given undue consideration or importance. The quality of justice and the fulfillment of the mandate of the Tribunal, including the establishment of a complete and accurate record of the crimes committed in the former Yugoslavia, must not be compromised. ${ }^{70}$

We salute the critical perspective adumbrated here by the Trial Chamber. Although intangible, we would agree that there is a qualitative element to justice that transcends bureaucratic management concerns and raw number of convictions.

\footnotetext{
$69 \quad$ Id. para. 54.

70 Id. paras. 65,67 . On the other hand, the Trial Chamber also pointed out its perceptions regarding the benefits of plea bargaining. Id. paras. 68-72. These benefits correspond to those that redound throughout the entire jurisprudence of the ICTY and that we have discussed earlier.
} 
In the end, in issuing sentence the Trial Chamber departed from the plea agreement. Under the agreement, the Prosecutor had recommended a sentence between 15 and 20 years, the defence a sentence of 10 years, and Nikolić explicitly had waived his right to appeal any sentence within the agreed-to range. ${ }^{71}$ The Trial Chamber concluded that the agreed-to range was inadequate and sentenced Nikolić to 27 years, noting that he had a right to appeal this sentence.

That said, it is disappointing that the concerns raised in the Nikolic case only affected the quantum of sentence in a seemingly ad hoc fashion. The ICTY did not establish a framework for when it should disregard the Prosecutor's recommendation, citing only its power to do so and, thereby, added an additional level of indeterminate discretion to the sentencing process. In fact, it contrasted its positive law framework with that of national courts and noted that in many national jurisdictions particular charges are accompanied with mandatory sentencing ranges. This means that national prosecutors can transparently impact sentence by deciding which charges to agree to in a plea. ${ }^{72}$ At the ICTY, there are no minimum or maximum sentencing ranges that attach to any crime. The ICTY took this to buttress its understanding as to its discretionary authority in sentencing, including the legitimacy of deviating from the ranges recommended in the plea agreement. ${ }^{73}$

Moreover, although the Deronjić opinion is dotted with concerns regarding plea bargaining (many of these drawing directly from the Momir Nikolić opinion), these concerns had no material effect in terms of the majority's disposition and punishment. In fact, many plea agreements considered by the ICTY following Momir Nikolic have not received any critical assessment at all. ${ }^{74}$ In the end, despite the emergent dissensus, the fact remains the Trial Chambers have affirmed most of the plea bargains and plea agreements (and the recommended sentencing ranges) that have come before them.

\footnotetext{
$71 \quad$ Id. paras. 172,173 .

$72 \quad$ Id. para. 56.

$73 \quad$ Id.

74 One exception is Dragan Nikolić. In this case, the defendant and Prosecution entered a plea agreement in which the defendant pleaded guilty and the Prosecutor recommended a sentence of 15 years. The ICTY, citing similar concerns to those it had raised in Momir Nikolić, and also citing the brutality and gravity of the crimes, instead imposed a sentence of 23 years. Another exception is Babić, where the Trial Chamber imposed a sentence of 13 years despite plea agreement recommendation of no more than 11.
} 
B. Guilty Pleas and the ICTY's Positive Law Instruments

We now provide some additional textual discussion of how guilty pleas are conceptualised within the foundation documentation of the ICTY, ${ }^{75}$ drawing comparisons with the more recent approach of the ICC.

As noted earlier, reference to guilty pleas appears in the ICTY's Rules of Procedure and Evidence, Rule 62 bis which states that:

If an accused pleads guilty in accordance with Rule 62 (vi), or requests to change his or her plea to guilty and the Trial Chamber is satisfied that:

(i) the guilty plea has been made voluntarily;

(ii) the guilty plea is informed;

(iii) the guilty plea is not equivocal; and

(iv) there is a sufficient factual basis for the crime and the accused's participation in it, either on the basis of independent indicia or on lack of any material disagreement between the parties about the facts of the case,

the Trial Chamber may enter a finding of guilt and instruct the Registrar to set a date for the sentencing hearing.

The Appeals Chamber in Erdemovic ${ }^{76}$ held that for a plea to be regarded as voluntary the accused must be mentally capable of comprehending the consequences of pleading guilty without any threats, inducements or promises. The fact that guilty pleas must be informed reflects the finding of the Appeals Chamber in Erdemovic ${ }^{77}$ that the accused

\footnotetext{
75 The foundational documents of the ICTR are virtually identical in this respect, except that Rule 62(B)(i) adds the word 'freely' to 'voluntarily' and the reference in Rule 62(B)(iv) is changed from 'independent' to 'objective' indicia.

76 Prosecutor v. Erdemović (Case No. IT-96-22-A), October 7, 1997, Joint Separate Opinion of Judge McDonald and Judge Vorah, at para. 10.

77 Ibid., at para., 75.
} 
in that case had not originally understood the nature of the charges or the consequences of pleading guilty to them. ${ }^{78}$

There was initially no reference or discussion in the ICTY's Rules of Procedure and Evidence regarding the effect of any plea agreement made between the Prosecutor and the Defence on the accused's behalf. The Trial Chamber in Erdemovic ${ }^{79}$ was the first to take a plea agreement into account when determining sentence, making clear that such agreements should be concluded on the initiative of the parties without any contribution or encouragement from the Trial Chamber. It was also unequivocal in stating that plea agreements should be in no way binding upon the Trial Chamber. In consequence, Rule 62 ter was adopted into the ICTY's Rules of Procedure and Evidence on December 13, 2001. This provides:

(A) The Prosecutor and the defence may agree that, upon the accused entering a plea of guilty to the indictment or to one or more counts of the indictment, the Prosecutor shall do one or more of the following before the Trial Chamber:

(i) apply to amend the indictment accordingly;

(ii) submit that a specific sentence or sentencing range is appropriate;

(iii) not oppose a request by the accused for a particular sentence or sentencing range.

(B) The Trial Chamber shall not be bound by any agreement specified in paragraph (A).

(C) If a plea agreement has been reached by the parties, the Trial Chamber shall require the disclosure of the agreement in open session or, on a showing of good cause, in closed session, at the time the accused pleads guilty in accordance with Rule 62 (vi), or requests to change his or her plea to guilty

78 The case was subsequently remitted to a second Trial Chamber so that the accused could make an informed plea.

Prosecutor v. Erdemović (Case No. IT-96-22), Sentencing Judgement, March 5, 1998, at para. 19 
The relationship between Rule 62 bis and Rule 62 ter is clear to the extent that any plea agreement may be taken as sufficient indication that there is a sufficient factual basis for the crime and the accused's participation in it. However, Rule 62 bis contains nothing to indicate what the consequences of entering or changing a plea to guilty should be in terms of its impact on the determination and length of sentence, whether that plea is the subject of a plea agreement or not. Certainly, no possibility of a 'plea bargain' is canvassed in the Rules of Evidence and Procedure in the sense of any guaranteed discount resulting from a change of plea depending on the stage at which it is entered. ${ }^{80}$ As with the decision to accept a plea, the effect of its timing is left to the discretion of the judges in the Trial Chamber. The Trial Chamber in Todorovic ${ }^{81}$ suggested that the public advantage to be derived from the Tribunal's truth-finding function would only be served if pleas entered before the commencement of the trial were rewarded with the full appropriate $^{82}$ discount. These comments were subsequently endorsed by the Trial Chamber in the Sikirica case where the accused failed to receive full credit because of the lateness of his plea. ${ }^{83}$

$80 \quad$ Such a possibility was mooted in England and Wales by the Auld Report, Review of the Criminal Courts (London: Lord Chancellor's Department, Sept. 2001).

$81 \quad$ Todorović, para.31.

82 See also Češić, para. 59 (noting that pleas concluded early in the process, especially if entered before trial, are particularly favourable). What counts as appropriate is, of course, a matter for conjecture. In England and Wales, for example, a one-third discount for a timely plea has conventionally been the norm for an early plea. Suggested guidelines recently issued by the Sentencing Guidelines Council offer a graduated scale ranging from one-third where the plea is entered at the first reasonable opportunity to less than one-tenth where it is entered after the trial has begun. The crucial variable is the offender's willingness to admit guilt so that in exceptional circumstances it is suggested a reduction of greater than one-third might be appropriate for 'a particularly early admission of guilt, or where absolute candour is demonstrated by an offender, or where the offender admits a crime that was either unknown to the authorities or in relation to which there was no evidence against him.'; Sentencing Guidelines Council, Draft Guideline-1:

Reduction in Sentence for a Guilty Plea, August 2004, at page 5, available online at http://www.sentencingguidelines.gov.uk/draftguidelines/guiltypleas/foreword.html. Jorgensen cites a report suggesting that the Prosecutor in Erdemović advocated a sentence discount of between 50 and 75 per cent for an accused who pleaded guilty and cooperated with the Prosecution; N. H. B. Jorgensen, The Genocide Acquittal in the Sikirica Case Before the International Criminal Tribunal for The Former Yugoslavia and the Coming of Age of the Guilty Plea, 15 LEIDEN J. INT'L L. 389 (2002), at p. 401, footnote 76.

${ }_{83} \quad$ A significant argument discussed by Jorgensen concerned the Defence contention in Sikirica that the full extent of the accused's personal culpability in terms of his role at the Keraterm camp could only have been revealed by delaying his guilty plea until after the conclusion of both the prosecution and defence evidence and that substantial credit should still have been given for it. Jorgensen, supra note Given that the Prosecutor would not have accepted a plea to charges of persecution prior to the commencement of the case, nor while genocide charges were pending, the Defence argued that the plea eventually entered by the accused should have been treated as one made at the outset but on the basis of the actual factual basis revealed during the course of the trial. This argument was rejected by the Trial Chamber. 
The ICTY Statute and Rules of Procedure and Evidence provide a fairly minimalist framework for the practice of sentencing and its principled development. Article 24 of the ICTY Statute provides (inter alia) that the Trial Chamber should take into account such factors as the gravity of the offence and the individual circumstances of the convicted person. In addition to setting the maximum term upon conviction to life imprisonment ${ }^{84}$ Rule 101 of the ICTY Rules of Procedure and Evidence also provides (inter alia) that the Trial Chamber shall take into account any aggravating circumstances and any mitigating circumstances, including the substantial cooperation with the Prosecutor by the convicted person before or after conviction; and the general practice regarding prison sentences in the courts of the Former Yugoslavia.

Because judges in the ICTY have been left with a largely unfettered sentencing discretion under the terms of its foundation instruments, Trial Chambers have increasingly adopted an individualised approach to sentencing. ${ }^{85}$ For various reasons, but especially due to its reluctance to categorise the crimes listed in the ICTY Statute in terms of their gravity, the ICTY Appeals Chamber has refused to be drawn towards the development of a definitive list of sentencing factors or a common approach to sentencing particular categories of crime ${ }^{86}$ Accordingly, sentences in the ICTY are largely determined on an individualised basis, taking account of the gravity of the offence ${ }^{87}$ and the degree of responsibility of the accused, together with the impact of relevant aggravating circumstances. Although ICTY judges have access to a broad range of information to assist them in achieving their objectives ${ }^{88}$ the weight to be accorded to the evidence

$84 \quad$ See further, W. Schabas, Sentencing and the International Tribunals: For a Human Rights Approach, 7 DUKE J. INT'L \& COMP. L. 461 (1997) available online at http://www.law.duke.edu/journals/djcil/articles/djcil7p461.htm

85 This is facilitated by the fact that, in practice, the ICTY regards the sentencing practice in the courts of the Former Yugoslavia as merely indicative of the approach to be taken in any particular case. 86 The general approach of the ICTY is to be found in the Čelebići Appeals Judgement of February 20, 2001; see Prosecutor v Delalić et al. (Case No. IT-96-21), Appeals Chamber, Judgement, February 20, 2001, at paras. 710-724. The following contains the most significant passage: 'The Appeals Chamber accordingly concludes that it is inappropriate for it to attempt to list exhaustively the factors that it finds should be taken into account by a Trial Chamber in determining sentence. The sentencing provisions in the Statute and the Rules provide Trial Chambers with the discretion to take into account the circumstances of each crime in assessing the sentence to be given.'

87 See further, M. Frulli, Are Crimes against Humanity More Serious than War Crimes?' 12 EUROPEAN J. INT'L L. 329 (2001); A. Carcano Sentencing and the Gravity of the Offence in International Criminal Law, 51 INT'L \& COMP. L. QUARTERLY, 583 (2002).

$88 \quad$ For example, Rule 85(A)(vi) of the ICTY Rules provides that the parties may produce 'any relevant information that may assist the Trial Chamber in determining an appropriate sentence if the accused is found guilty on one or more of the charges in the indictment.' 
therefore continues to depend on judicial discretion exercised according to the circumstances of each individual case. ${ }^{89}$

The failure of the ICTYs foundation instruments to suggest how particular sentencing factors might be balanced within the context of different sentencing purposes for each category of crime is a serious omission for a variety of reasons. Firstly, the absence of any guidance regarding how to operationalise different ideologies for punishment makes it easier for the predominantly retributive dynamic of the ICTY penality to prevail. Secondly, and in consequence, the potential for the sentencing process to contribute towards the achievement of legitimate goals for victims and post-conflict societies is reduced considerably. Finally, and of special significance for the present discussion, the absence of a rational and principled approach to reconciling competing claims for justice and overreliance on individualism and unfetterred discretionary power means that there is no institutional resistance to the control ideology of plea bargaining. It is for this reason that the weak ideological and normative structures of trial justice in the ICTY currently facilitate the exponential growth of plea agreements.

In similar vein to the ICTY, the ICC Statute (Article 65) provides that, where the accused admits guilt under Article 64.8.(a), the Trial Chamber must satisfy itself as to the voluntariness of the admission, that the accused understands the consequences, and that the admission is supported by the charges and factual evidence then available to it. ${ }^{90}$ Article 65.3 . goes on to

\footnotetext{
89

In his recent detailed analysis of the sentencing practices of the ad hoc tribunals, Beresford identified the following main aggravating factors as commonly taken into account: the scope of the crime; number and suffering of the victims; form of participation; motive; superior responsibility. Mitigating circumstances included: the plea of guilty; personal circumstances (emotional condition of the accused, background of the accused, effect of sentence on others where unusual hardship likely to result, conduct of the accused since the commission of the offence); good character; superior orders; level of participation in the crimes; disorder ensuing from an armed conflict; S. Beresford Unshackling the Paper Tiger: The Sentencing Practices of the ad hoc International Criminal Tribunals for the Former Yugoslavia and Rwanda, 1 INT'L CRIM. L. R. 33 (2002)

$90 \quad$ For further detail see, H-J Behrens Investigation, Trial and Appeal in the International Criminal Court Statute (Parts V, VI, VIII) 6 EURO. J. CRIME, CRIM. L., \& CRIM. J. 429 (1998). Schabas supports the view that the ICC Statute achieves an acceptable pragmatic compromise in reconciling the opposing philosophical approaches to the concept of the guilty plea characteristic of common law and civil law jurisdictions W. Schabas An Introduction to the International Criminal Court (Cambridge: Cambridge University Press, $2^{\text {nd }}$ ed, 2004) at page 150. It is worth noting that in England and Wales, when the offender pleads guilty the judge does not hear the evidence, only the prosecution's statement of facts. Disagreements relating to the factual basis for sentencing may be resolved by a 'Newton hearing.' For further discussion see, A. Ashworth Sentencing and Criminal Justice (London: Butterworths, 2000) at pages 308-311. The ICC Statute (Article 65.4.) goes further than this in providing that the Trial Chamber
} 
state that, if the Trial Chamber is not satisfied that that these conditions are established, it may deem the guilty plea as not having been made and proceed to trial. The presumption of innocence is enshrined in Article 66, which also confirms that the onus is on the prosecution to prove to the satisfaction of the Court that the accused is guilty beyond all reasonable doubt.

The negotiations which preceded the formulation of the rules for the acceptance of guilty pleas in the ICC Statute were notable for the apparent misconception and suspicion on the part of civil law countries regarding the nature, effect and consequences of a guilty plea as commonly understood in common law jurisdictions. ${ }^{91}$ However, as Behrens ${ }^{92}$ points out, whilst the original ILC Draft ${ }^{93}$ was treated with circumspection since it failed to specify the consequences of a guilty plea, detailed comparisons of the criteria applied by judges in both trial styles in the sessions of the Preparatory Committee revealed remarkable similarities - particularly as regards judicial checks on whether the plea was made voluntarily and in full knowledge of the consequences. Thus, the debate as to whether the procedure should be termed 'a guilty plea', 'confession of guilt', or, 'admission of guilt' became superfluous, as is the provision eventually added to the ICC Statute (Article 65(5)), which states:

Any discussions between the Prosecutor and the defence regarding modification of

the charges, the admission of guilt or the penalty to be imposed shall not be binding

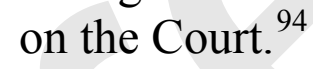

However, the ICC Statute and the Rules of Evidence and Procedure are correspondingly silent regarding the impact of a guilty plea on sentence. For

may request the Prosecutor to present additional evidence (including witness testimony) in order to satisfy itself that a more complete presentation is made in the interests of justice.

91 See Behrens, supra, note 17. But see discussion infra text at note 133, in which convergences between common law and civil law approaches to guilty pleas are noted.

Ibid., at page 439.

93 ILC Draft, Article 38, para. 1 lit.d) (UN-Document A/49/10, p110 ff.). As Behrens interestingly observes, the Appeals Chamber in Erdemović (decided during this phase of the negotiations) were forced to re-open the proceedings following the revelation by the accused that his guilty plea had been entered under duress and he had not been informed precisely about the nature of his plea. Behrens, supra note _, at page 459 ,

$94 \quad$ Schabas, supra note _ _, at page 150, suggests that this provision was forced because of a general misconception on the part of certain civil law countries that undertakings between the prosecutor and the judge were binding at common law. 
instance, Article 76.1. refers only to the Trial Chamber's obligation to 'take into account the evidence presented and the submissions made', whilst Article 78.1. points vaguely to offence gravity and individual circumstances as being relevant to the determination of sentence. Rule 145 of the Rules of Procedure and Evidence does little more than explicitly mention the relevance of aggravating and mitigating circumstances (Rule 145.1.(b)), give further examples of individual circumstances (Rule 145.1.(c)), and provide two examples of mitigating circumstances (Rule 145.2.(a)(i) and (ii)). Nowhere is there any explicit recognition or consideration of the following crucial issues:

- Whether a guilty plea counts as a mitigating factor.

- If so, what conditions, circumstances or principles should govern the impact that the guilty plea has on the final sentence determination.

The absence of any discussion of these matters, or their elaboration in the ICC Statute or Rules, is a matter of considerable concern.

The absence of rationalisations for sentencing within the foundation instruments of the ICTY means that there is no clear basis for justifying the use of guilty plea discounts for those convicted of the specified international crimes. This lack of rationality is reflected in the confusion which appears to persist in decisions of the ICTY - which we set out in Part A.(b) above - as to whether the guilty plea is a mitigating factor justifiable on the basis of the accused's alleged remorse or contrition.

There are two interconnected issues raised by this debate which arguably should have received attention and clarification in the foundational documents of the ICTY. The first concerns the status of the guilty plea as a mitigating factor, and the second relates to whether remorse, cooperation, and accepting responsibility should be treated as entirely separate factors from the guilty plea in their effects upon sentence. The notion that remorse should be considered separately from the guilty plea as mitigation is consistent with aspects of both inquisitorial and adversarial criminal procedure, since it is often absent from the former, and of little relevance to the latter. ${ }^{95}$ Some of the ICTY's jurisprudence leans in this direction. That

95 See R. Henham Sentence Discounts and the Criminal Process (Aldershot: Ashgate Publishing, 2001). 
said, there is an unprincipled element to this jurisprudence, leading to the concerns we identified earlier in Part A.(b) regarding cumulative mitigation. Although it may be argued that pleading guilty is in some way an 'acceptance of responsibility, ${ }^{, 96}$ the problem remains that whether the defendant accepts responsibility because he is truly contrite, or for tactical reasons, is an inherently subjective issue. ${ }^{97}$ If the ICTY had made the purpose of guilty pleas clear in its Statute this would have paradoxically strengthened the position of those who would wish to defend it, and provided a clear rationale for its subsequent use in the Trial Chamber. Whilst we would clearly not endorse any such justification, a rational basis for action would have been preferable to the obfuscated reasoning and vacuum which currently persists. This substantially weakens the efficacy of the ICTY's professed search for 'truth', the perceived legitimacy of its outcomes and its ability to contribute in more constructive ways to the reconstruction of societies damaged by war and social conflict.

C. Beyond the Individual Defendant: Plea Bargains, Trial Ideology, and Truth-Telling

In this section we consider: (1) the relationship between plea bargaining and the trial ideology of the ICTY, in particular the tensions between legitimacy and pragmatics and the effect of these tensions on ICTY penology; and (2) the effects of plea bargains on truth-telling and reconciliation.

(a) Relationship of Plea Bargaining to Contrasting Models of Trial Justice for the Former Yugoslavia

What does the institutionalisation of plea bargaining as administrative policy within ICTY penality mean for models of trial justice? The purpose of this inquiry is to gauge the extent to which ICTY justice as presently conceived can be said to correspond with notions of what constitutes

\footnotetext{
96 As in the US Federal system. See also Sentencing Advisory Panel, Reduction in Sentence for a Guilty Plea, June 2004, available online at http://www.sentencingguidelines.gov.uk/c and a/advice/guilty pleas/foreword.html (the English Sentencing Advisory Panel's advice to the Sentencing Guideline Council on sentence discounts propounding that, since the rationale for the guilty plea is clearly based on system considerations, it should be unrelated to personal mitigation and considered separately).

97 It is even an argument for saying that a truly remorseful offender would be prepared to accept just punishment without any expectation of a reduction in sentence.
} 
legitimate punishment on the part of those significantly affected by the trial process. However, it should be recognised that the reconciliation of principles for international criminal justice with local demands for justice (such as those existing within the Former Yugoslavia) entails developing theory and modelling for understanding processual activity comparatively, in order to take account of cultural relativism and moral relativity. Consequently, an approriate analytical framework for understanding the complexities of trial decision-making, whether at the global or local level, is vital in deconstructing the social reality of decision-making in international criminal trials and providing the knowledge necessary to evaluate the prospects for trial transformation. ${ }^{98}$

The conventional starting point for any discussion of theoretical modelling of the criminal process in common law jurisdictions has been Packer's ${ }^{99}$ seminal distinction between crime control and due process. Whilst a paradigm of due process (such as Packer's) is not normatively prescriptive, it can be used to judge whether process measures up to a taxonomy of idealised due process characteristics. Despite the many qualifications and critiques of Packer's modelling, ${ }^{100}$ it remains important in highlighting fundamental distinctions affecting the balance between individual and system interests in criminal processes. ${ }^{101}$ These distinctions might be portrayed for international criminal justice in terms of the following basic paradigms of trial justice:

(i) The pragmatic model - in this conceptualisation judges equate trial justice as consistent with the achievement of system objectives. Hence, the ideology of international trial justice is conveyed through symbolism and rhetoric. In this model guilty pleas/plea agreements are valued as contributing to the achievement of bureaucratic goals of speed, efficiency and the maximisation of resources. ${ }^{102}$

\footnotetext{
98 For detailed discussion of these issues see, M. Findlay and R. Henham Transforming Criminal Justice: retributive and restorative justice in the trial process (Cullompton: Willan Publishing, forthcoming).

99 H. Packer The Limits of the Criminal Sanction (Stanford: Stanford University Press, 1969)

100 Most significant being his failure to account for context and power variables. For a useful summary see, L. Zedner Criminal Justice (Oxford: Oxford University Press, 2004) at pages 116-120.

$101 \quad$ Hudson suggests that tensions between liberty and security are replicated for criminal justice in the due process/crime control dichotomy; B. Hudson Justice in the Risk Society: Challenging and Reaffirming Justice in Late Modernity (London: Sage Publications, 2003).

102 This model appears largely consistent with Packer's notion of crime control except that the paradox between crime control and due process lies in the significant discretionary power of international judges. The impetus against due process is therefore driven by judicial power exercised pragmatically.
} 
(ii) The legitimacy model - here trial justice is conceived in terms of a synergy between ideology and outcomes. Consequently, international criminal trials are seen as transformative structures whose primary function is to provide the means of reconciling the ideology and the morality of punishment for victims and post-conflict societies. This model conceives of guilty pleas/plea agreements as lacking in moral legitimacy in the context of trial justice because they do not serve rationalisations for punishment. Although it may be argued that enhancing the speed of punishment, saving court time and expense, absolving the need for victim/witness testimony, encouraging cooperation with the authorities and the further identification of suspects are all beneficial consequences of plea bargains, none of these rationalisations are concerned with supporting an ideological purpose for international penality which has moral legitimacy in the eyes of all the significant players in the ICTY process. ${ }^{103}$

Whilst our analysis of plea bargaining in the ICTY suggests that Trial Chambers, despite the apparent reservations announced in Momir Nikolić, currently favour a pragmatic model of trial justice, we argue strongly for a reconceptualisation favouring justice principles which correspond more closely with what trial participants regard as their legitimate expectations for punishment, whether they be retributive, restorative or mixed. In effect, we are suggesting that there should be a shift in the ideological justification for trial justice predicated upon the ideal of using the trial and punishment process as a means of harmonising and satisfying (as far as possible) conflicting demands for justice. ${ }^{104}$ The existence of this ideological commitment (currently absent from the ICTY's foundational instruments) will serve to promote due process and ensure that the discretionary power of Trial Chamber judges is utilised constructively in the process of developing a more polycentric and, perhaps, restoratively-orientated framework for transitional justice in post-conflict societies such as the Former Yugoslavia.

As currently conceptualised, there is an inherent philosophical contradiction in the arguments advanced in support of the restorative capability of plea agreements in international criminal trials. Firstly, the ICTY cannot effectively divorce itself from the administrative efficiency argument. In Momir Nikolić, for example, the Trial Chamber essentially

103 The legitimacy model goes beyond Packer's notions of due process because it focuses on the moral reasons for principles of trial justice.

$104 \quad$ For further elaboration of these arguments, see Findlay and Henham, supra note 
tried to argue that the trial ideology of the ICTY forces a reconceptualisation of plea agreements. ${ }^{105} \mathrm{We}$ are asked to suspend belief in those rationales and implications that do not sustain the ICTY's professed search for 'truth' (such as, control of process; suppression of evidence; exclusion from participation; denial of process; erosion of rights; absence of public accountability) in return for a vision of plea agreements as procedural mechanisms that nurture the ideological thrust of international penality towards achieving the constructive ideals of reconciliation and reconstruction. Without denying that this may be one effect of plea agreements, it is equally important not to overstate the truth-telling and reconciliatory effects of plea agreements, as we argue in Part C (b) below. Nevertheless, rhetoric about the restorative capabilities of plea agreements conveniently ignores the substantive reasons for their increased use in common law jurisdictions in recent years. ${ }^{106}$ It emphasises a justification for their continuation and expansion that effectively redefines the underlying rationale for the existence of plea agreements as procedural expedients.

In its discussion of Principles and Purposes, ${ }^{107}$ The Trial Chamber in Momir Nikolić made no real attempt to take the issue of rationality further than in previous cases. The Trial Chamber's analysis provides a very circumscribed and one-dimensional view of its penality, dominated by the perception that the objectives of international punishment are somehow achievable through simple enforcement of the rule of law. This is most apparent in its discussion of deterrence:

One of the main purposes of a sentence imposed by an international tribunal is to influence the legal awareness of the accused, the surviving victims, their relatives, the witnesses and the general public

105 The Trial Chamber was at pains to stress the dual conception of trial ideology for the ICTY; that of putting an end to impunity for those who perpetrate gross breaches of international humanitarian law, on the one hand, and contributing to peace and reconciliation, on the other. Momir Nikolić, paras. 58-62. It used this ideology to distinguish its mandate from national criminal justice systems by arguing that the principled use of plea agreements actually made a constructive contribution towards full accountability, and distanced itself (implicitly) from the remarks of Judge Cassese in Erdemović supporting their use for (inter alia) reasons of bureaucratic and administrative expediency. In so doing, the Trial Chamber again stressed the argument that guilty pleas can often make a significant contribution to peace and reconciliation, particularly when coupled with sincere expressions of remorse. Id. para. 72. Procedural safeguards would ensure that the interests of 'justice' were not compromised.

106 Notwithstanding their tacit or overt acceptance in an increasing number of civil or hybridised jurisdictions in recent years; see further, F. Tulkens 'Negotiated Justice' in M. Delmas-Marty and J. R. Spencer (eds.) European Criminal Procedures (Cambridge: Cambridge University Press, 2002) at pages 641-687.

$107 \quad$ Momir Nikolić, paras. 127-140. 
in order to reassure them that the legal system is implemented and enforced. Additionally, the process of sentencing is intended to convey the message that globally accepted laws and rules have to be obeyed by everybody. 'All persons shall be equal before the courts and tribunals.' This fundamental rule fosters the internalisation of these laws and rules in the minds of legislators and the general public. $^{108}$

In effect, the Trial Chamber is arguing that international sentencing has a pedagogical function in terms of re-enforcing adherence to the rule of law; it promotes consistency and equality of treatment - no-one can escape with impunity; it also suggests that public denunciation through punishment has more than an educatory function - it promotes the internalisation of the values implicit in the declared ideology of the ICTY. The utilitarian message underlying this passage is that retributive and deterrent justifications are operationalised through sentencing into outcomes which are inherently moral because they sustain the rules of international humanitarian law. This assumed transformation of ideology into informed moral action on the part of the intended audience is highly conjectural. The passage implicitly acknowledges the symbolic importance of public denunciation as an aspect of deterrence, invoking the Durkheimian notion that the universally accepted morality of the tribunal's mission (and its underlying rationality) is sufficient to justify punishment in terms capable of identifying, reconciling and satisfying demands for global and local justice.

However, this assumption is seriously flawed and raises some fundamental questions which go to the legitimacy of international criminal justice. For example, is it realistic to suggest that law (or, more specifically, punishment norms) effectively influence the internalisation of morals? Similarly, can universally accepted moral principles be transformed into normatively effective principles for action through sentencing? The answers to these questions are by no means clear. ${ }^{109}$ What does seem certain, however, is the need for legal and processual norms to be perceived as legitimate by those who are significantly affected by their operation. The fact that such norms exist to give effect to universally held moral principles may be sufficient for both to be regarded as legitimate in the eyes of the

$108 \quad$ Id. para. 139.

109 See further, R. Henham Theory and Contextual Analysis in Sentencing 29 INT'L. J. SOC. L. 253 (2001). 
wider international community. However, it is important to distinguish the fact that, for victims and others affected by social conflict, legitimacy also depends on whether international punishment actually resonates with understandings of local penality.

Attempts by the ICTY to redefine or reposition plea agreements in recent case law compound the obfuscation already apparent in the model for justice delivery underwritten by the international criminal institutions, as personified by the trial and the ideology of trial justice. As we have argued, the moral legitimacy of the international trial form and its ideological justification, although symbolised by a universal appeal to humanitarian principles, is, nevertheless, grounded in the penality of retributivism and, secondarily, deterrence. Particularising ownership of the universal requires a paradigm shift in trial ideology through the recognition that the legitimacy of trial justice must have concrete (i.e. contextual) significance and that this legitimacy is largely communitarian in significance. Consequently, procedural norms are context specific to the exten that their legitimacy can only be assessed within the ideological framework in which they operate.

A paradox emerges between the ideology and practice of plea bargaining within the predominantly retributive context of international penality. We have seen how the foundation instruments of the ICTY and the ICC, coupled with the wide discretionary powers given to international judges in sentencing matters, allow international sentencers (albeit largely eclectically) to promote retributive as well as utilitarian justifications for punishment. Any repositioning of ICTY trial ideology should focus on maximising the instrumental capacity of discretionary decision-making for accommodating retributive and reductivist considerations at important decision sites within the trial (such as sentence). Such an ideology ought to recognise that the legitimacy of international penality depends on the integration of victims and victim communities, and that this should be ideological and normative. If the discretionary power of ICTY judges was available to pursue legitimate restorative outcomes beyond those that follow from the determination of guilt or innocence, plea agreements and other forms of processual negotiation might be re-defined in more constructive terms.

(b) Effects of Plea Bargaining on Transitional Justice: TruthTelling and Reconciliation 
The ICTY declares that 'a guilty plea is always important for the purpose of establishing the truth in relation to a crime. ${ }^{110}$ It also has held that guilty pleas ' $[\mathrm{u}]$ ndoubtedly tend[] to further a process of reconciliation. ' ${ }^{111}$ Is the ICTY's optimism justified? We recognise that when the ICTY (or any other trial institution) asserts that plea or other processual negotiation can contribute to peace and reconciliation, ${ }^{112}$ it does so within a particular ideological context (and, in this case, to promote particular pragmatic needs). This is not to deny the reality of what is asserted; rather, it simply recognises that normative behaviour is controlled and legitimised by ideology and policy. ${ }^{113}$ On the other hand, just because that the ICTY asserts a good faith belief that plea bargains promote truthtelling and reconciliation does not mean that this belief ought to be relieved or immunised from scrutiny. A contrario, this invites subjecting that belief to rigourous examination.

Any assessment of the relationship between plea agreements, on the one hand, and truth-telling, restoration, and reconciliation, on the other, must assess - in a forthright manner - the consequences of the three levels of discount that inhere in negotiated pleas, in particular charge bargains.

First, there is a reduction in the severity of sentence for the charges to which the offender actually pleads guilty. In Part A of this paper, we detailed the quantum of reduction in the overall data. This reduction animates concerns within victim communities as to whether the ICTY is attaining its

110 Todorović, para. 81 (cited in Mrdja, para. 76). See also Češić, para. 58 ('The Trial Chamber accepts that the guilty plea helps to establish the truth and may aid the process of reconciliation in the Brcko municipality. More particularly, a guilty plea, whereby an accused recognises his/her responsibility and specifies the circumstances in which the crimes were committed, is likely to provide a sense of relief to the surviving victims and the victims' relatives and friends. A guilty plea also saves the witnesses from the possible trauma of re-living the events while testifying in court.' See also Sikirica, para. 149 ('a guilty plea contributes directly to one of the fundamental objectives of the international tribunal: namely, its truthfinding function.'). But see also Deronjić, para. 134 (ICTY Trial Chamber coming to a somewhat contradictory position by holding that it 'is not the final arbiter of historical facts,' as that 'is for historians').

111 Deronjić, para. 134. See also Plavšić, paras. 70-80 (emphasising truth and reconciliation effects of plea bargains).

${ }_{112}$ Obrenović, para. 112 (citing comments of a Bosnian Muslim from Srebrenica that the defendant's plea and confession, while far from an apology, brought relief and acknowledgement).

113 A specific example of how such control might be exercised is through the principle which asserts that no accused should be penalised for exercising the right to go to trial and have the prosecution prove its case. As suggested earlier, experience from common law jurisdictions confirms that trial ideology controls the operation of this principle to the disadvantage of those opting for full trial through the so-called 'trial penalty'; see, C. McCoy and R. Henham Guilty Plea Discounts in American and English Courts: An Empirical Description and Ethical Critique of the Trial Penalty (2004) available online at http://www.nls.ntu.ac.uk/CLR/ICTP/index.htm. 
retributive aspirations. There is a mixed record of public response when perpetrators of mass atrocity plead guilty. ${ }^{114}$

Second, and more germane to concerns over truth-telling and reconciliation, the offender discounts the public process of the trial and generally pleads guilty only to the bare factual allegations in an indictment, instead of contending with the gruesome, detailed evidence admitted in trial and necessary to convict on those allegations. What is more, the offender does not have to face victims in court and, although some victims may not relish testifying, for others providing viva voce testimony may be a salutary expressive experience. Witnesses are only rarely called when a Trial Chamber has to validate a plea agreement, although they may be called at the sentencing hearing. This second level of discount could be mitigated if the sentencing hearing became a space where witnesses and victims could testify, or at least provide victim impact statements, such that the sentencing hearing would become a public and expressive forum.

That said, the public narration of the tragedy and the attendant cathartic consequences that could arise from an expanded sentencing hearing are undercut by the third level of discount, namely that the offender usually bargains for the Prosecutor to drop a number of charges. ${ }^{115}$ For example, in the Plavšić plea bargain affirmed by the ICTY, Plavšić pleaded guilty to one count of persecution as a crime against humanity and the Prosecutor dropped the remaining seven charges, including two counts of genocide and complicity in genocide. The plea bargain therefore buries many allegations and consequently erases those victims and bars the determination of the truths of their claims. The allegations themselves become no more than withdrawn charges or, worse, a bargaining chip.

This also was the case in the Deronjić plea bargain, which established the truth only regarding the tragedy that encompassed one village on one particular day, thereby obfuscating several other potential truths - namely

\footnotetext{
114 See Combs, supra note _, at 936 (discussing public responses to the Plavšić guilty plea in Serb, Croat, and Bosnian Muslim communities and noting that 'truth telling is one thing; deal cutting is another.').

115 See, e.g. Mrdja (charge of crime against humanity dropped as part of the plea bargain); Deronjić, paras. 14, 18 (six counts in original indictment reduced to one charge in plea agreement); Momir Nikolić (plea bargain involved the Prosecution dropping the genocide charges); Babić (pleaded guilty to one count of persecution as a crime against humanity in exchange for the Prosecutor agreeing to drop four other charges).
} 
accusations involving other spaces and places in Bosnia. ${ }^{116}$ That said, the Deronjic judges, although emphasising truth-telling and reconciliation as a rationale supporting plea bargaining, also recognised evident limitations to this rationale by concluding that 'this Tribunal is not the final arbiter of historical facts. That is for historians. For the judiciary focusing on core issues of a criminal case before this International Tribunal, it is important that justice be done and be seen to be done, within the ambit of the Indictment presented by the Prosecution. ${ }^{117}$ For Judge Schomburg, in dissent, the Prosecutor should have presented all the evidence available. From his perspective, concerns of judicial economy call for limiting charges only if a just judgement remains possible: 'The test should be, whether individual separable parts of an offense or several violations of law committed as a result of the same offense are not particularly significant for the penalty to be imposed. ${ }^{118}$ In his mind, the Deronjić agreement did not meet this test. Judge Schomburg's approach would retool the ICTY's approach to plea bargaining in a manner that already may be contemplated by the extensive jurisprudence regarding concurrent sentencing, but would also provide room for more truths to emerge unless such truths were redundant.

There is some evidence that decisions by the Prosecution to drop charges to secure pleas to other charges frustrates victims, sows arbitrariness, and weakens legitimacy. ${ }^{119}$ For example, following the Obrenović and Momir Nikolić plea agreements, groups representing families of the victims 'expressed hurt and outrage that the charges of complicity with genocide ... were dropped. In their eyes this was tantamount to the tribunal saying that genocide did not take place. ${ }^{120}$ Those cases in which genocide charges are dropped present a unique situation insofar as the charge bargaining means that the 'crime of all crimes' is not determined to apply to a particular situation. To be sure, the ICTY Prosecutor has experienced difficulty in securing genocide convictions, and the only violence thus far officialised as genocide is that which occurred in Srebrenica. However, when claims are bargained away so, too, is the chance not just to tell the truth, but advance the argument that what happened in other places also amounted to genocide.

\footnotetext{
116 Deronjić dissenting judgement, para. 4.

117 Deronjić, para 135.

118 Deronjić dissenting judgement, para. 8.

119 Simons, supra note

120 Srebrenica Justice Campaign, Bulletin No. 7 (January 2004) pp. 8-9 (on file with author).
} 
The upshot is that in the case of high-level accused (where the exacting nature of criminal law requires the leader to be traced to the body interred in the mass grave) plea bargains may offer a partial print of the truth whose value exceeds that of the acquittal that might result if the Prosecutor fails to satisfy the high threshold of proof required by the ICTY's Rules of Evidence. Many offenders who plead guilty do admit wrongdoing. Some express remorse - perhaps even apologise - and educate the public about the crimes in question. These offenders may even implicate others, although not all are willing to do so. For example, Plavšić has refused to involve anyone else in the violence or testify in any other cases. ${ }^{121}$ The bargained-for testimony of Momir Nikolić was subsequently found by the ICTY to be evasive and lacking in credibility. ${ }^{122}$ On the other hand, although it is too early for definitive proof of truth-telling, the convictions regarding Srebrenica (Krstić - which was by way of trial - and Plavšić, Obrenović, Momir Nikolić - each by plea agreement) may have played some role in the eventual admission of responsibility by Bosnian Serb leadership for the Srebrenica massacre. In June 2004, a report commissioned by Bosnia's Serb Republic admitted for the first time that units under the government's control 'participated' in the July 1995 massacre. ${ }^{123}$

Contrition may prove to be more forthcoming under the ICC, which, as we explore in Part B, speaks not of guilty pleas, but, rather, of proceedings on an admission of guilt. ${ }^{124}$ Assuredly, this is as of yet untested. Moreover, the intersection of the more inquisitorial approach of the ICC with the plea bargain remains foggy. Although plea bargains may fit more comfortably with the adversarial approach that characterises the ICTY, it is unclear how responsive they will be to inquisitorial modalities, at least as far as charge bargaining is concerned. To some extent, the legitimacy of plea bargains cannot be disentangled from broader conceptual debates regarding adversarial methodologies characteristic of the common law and inquisitorial methodologies characteristic of the civil law. In this vein,

$121 \quad$ Combs, supra note__. at 934.

122 Momir Nikolić, para. 156. See also Prosecutor v. Krstić, Case No. IT-98-33-A (ICTY Appeals Chamber, April 19, 2004) para. 94 (ICTY Appeals Chamber hesitating to rely independently on pleabargained testimony from Deronjić in the proceedings against Krstić owing to discrepancies in Deronjić's testimony and the ambiguity surrounding some the statements he made).

123 Nicholas Wood, Bosnian Serbs Admit Responsibility for the Massacre of 7,000, N.Y. TIMES (June $12,2004)$. The admission did not refer to the massacre as an act of genocide.

124 See Rome Statute of the International Criminal Court, U.N. Doc. A/CONF.183/9* (1999), arts. 6566. 
although our assessment of the merits of plea bargains is more functional in nature (i.e. how, if at all, do plea bargains advance or improve upon the goals of international criminal justice), it also is possible to situate plea bargains within a broader legal debate as to the suitability of inquisitorial or adversarial approaches to resolve mass criminality. That said, careful comparative analysis of municipal legal systems suggests that pleas are used - albeit to different degrees - in both civil law and common law systems, and used differently by nations within each legal tradition, thereby suggesting a fragmentation within each legal family. ${ }^{125}$ This may in fact indicate an overlapping convergence among legal systems and fragmentation within legal systems that suggest that comparative legal analysis may risk essentialising the differences among legal systems.

In the end, the relationship between plea bargains and transitional justice goals (which we would loosely describe as truth-telling, restoration, and reconciliation) is complex. We fault the ICTY for the simplistic causal connections it plots between plea agreements and the promotion of transitional justice. We also explore concerns that these connections may embellish the ICTY's actual motivations, namely managerial pragmatism. That said, we applaud the ICTY's declaration of the importance of transitional concerns and its attempt to engage the individualised criminal process as a vehicle to promote these collective, and often highly political, goals. At this point in time, it seems too early to conclude that plea agreements promote these transitional concerns in as clear a way as the ICTY hypothesises. We believe that more nuanced understanding of the connection between plea agreements and transitional justice is desirable. This would ensure that the positive aspects of plea bargains - namely, the dissemination of some truth and accountability - are not overshadowed by corrosive contempt among victim communities regarding the benefits that were doled out to perpetrators in order to obtain what may be pithy truths and shaky accountability. When such overshadowing occurs, plea bargains can impede transitional justice instead of fostering it.

\section{Conclusion}

125 Máximo Langer, From Legal Transplants to Legal Translations: The Globalization of Plea Bargaining and the Americanization Thesis in Criminal Procedure, 45 HARV. INT'L L. J. 1, 37-38, 62 (2004). 
We began this article by pointing to the need for some kind of theoretical framework to inform the plea bargaining practices of the ICTY. Our subsequent analysis has revealed inconsistency and obfuscation as regards the praxis of pleading guilty and plea bargaining and raised serious doubts about the contribution such practices can make to the achievement of peace and reconciliation in post-conflict societies beyond the furtherance of the purely system interests of the institutions of international criminal justice. Although we indicate a number of interrelated factors as responsible for this state of affairs, we suggest that the ideology of international trial justice as practiced in the ICTY may play a catalytic role. The pervading retributive ideology of ICTY justice and the normative framework supporting it, rather than resisting systemic pressures for concessions and compromise, displays a tendency towards facilitating their exponential expansion. There is little resistance because such an ideology, wherever operationalised, inevitably draws sustenance from measures that encourage retributive objectives, the control of narratives, and the efficient management of risk. In the present scenario, these tendencies are exacerbated by the unprincipled development of individualised sentencing, ${ }^{126}$ which promotes a form of eclecticism.

Our hopes are realistic. Assuredly, political realities, as well as time and resource constraints, may increase pressures to secure plea bargains for the ICTY. The challenge, both theoretical and practical, is to encourage an ideological shift in sentencing which recognises that a key to trial justice requires the pluralisation of ideology to include a consideration of diverse approaches, including restorative themes, in sentencing praxis. This does not imply an immediate wholesale change in the normative structure. ${ }^{127}$ It could be achieved quite straightforwardly in the short term ${ }^{128}$ by the Appeals Chamber setting about a reformulation of the purposes and practice of sentencing in a re-statement of aims and principles designed to draw the

126

This is not a contradiction in terms since it is arguably necessary to establish the ideal sentencing pattern for any given jurisdiction in order to combat the problems associated with subjective disparity. This should be achieved by first deciding upon the aim(s) of sentencing, or the order of priority among competing aims. At the very least, we suggest that any measures which militate against producing disproportionality between the seriousness of the offence and the sentence should be encouraged

127 Something which is evidently impractical in the case of the ICTY.

128 Solutions which involve providing authoritative lists of aggravating and mitigating factors, maintaining proportionality as the guiding principle giving way to individualisation in various types of cases, or relying on appeal systems to remedy subjective disparities are insufficient to offset the distorting effect of negotiated forms of justice. For a paradigm which envisages a constructive and strategic role for trial justice in the healing and rebuilding of broken communities and lives see, Findlay and Henham, supra, note _, ch. 8 . 
discretionary power of ICTY judges towards engagement with a much broader and polycentric range of sentence justification. We submit that such a theoretical re-structuring will at least provide a context within which the merits of plea bargains in individual cases can be rigourously assessed for their compliance with the broader interests of victims and victim communities rather than the narrow system interests which they currently seem to serve. Although these interests are not devoid of some benefit, we believe that international criminal justice can strive to do better, particularly as it deepens in confidence and maturity. 